\title{
Trendy vývoje koncentrací fosforu v nádržích Orlík a Slapy
}

\section{JOSEF HEJZLAR, JIŘí JAROŠÍK, JIŘí KOPÁČEK, YULIYA VYSTAVNA}

\author{
Klíčová slova: eutrofizace - retence fosforu - socio-ekonomické indikátory - změna klimatu
}

\section{SOUHRN}

Na základě datových řad pro koncentrace fosforu $(P)$ v nádržích Slapy a Orlík a $\vee$ jejich hlavních prítocích jsme zrekonstruovali vstup $\mathrm{P} z$ povodí do těchto dvou nádrží pro období 1961-2015 a sestavili nádržové modely retence P. Koncentrace $P$ v obou nádržích rostly od 60. let minulého století až do roku 1991 a pak začaly klesat, v nádrži Slapy ale s výrazně zvýšenou meziroční variabilitou. Trendy koncentračního nárůstu a poklesu P byly odrazem vývoje socio-ekonomiky v povodí Vltavy, zejména stavu kanalizací, vypouštění odpadních vod, aplikace hnojiv, množství hospodářských zviŕat a intenzity rybničního chovu ryb. Analýza retence $P \vee$ nádržích ukázala, že $P$ akumulovaný $v$ sedimentech nádrže $v$ době rostoucího zatížení $P$ z povodí $v$ letech 1961-1990 se v následujícím období poklesu zatížení P opět uvolňoval do vody a tlumil vliv poklesu koncentrací $P$ v prítoku do nádrží. Po roce 1991 se $\vee$ nádrži Slapy v letním období koncentrace $\mathrm{P}$ začaly za zvýšených letních průtoků zvyšovat a podporovat rozvoj fytoplanktonu, kdežto v suchých létech výrazně klesaly až k mezotrofii. Klimaticko-hydrologicky podmíněné procesy tak v poslední době zjevně působí proti klesajícímu trendu znečištění P a zvyšují eutrofizaci nádrže navzdory poklesu zatížení $P$ z povodí.

\section{ÚVOD}

Vysoké koncentrace fosforu (P) způsobující eutrofizaci jsou důvodem neplnění požadavku Rámcové směrnice vodní politiky EU (RVS) na dobrý ekologický potenciál u zhruba dvou třetin nádrží v ČR [1]. Jako u jiných polutantů, znečištění povrchových vod fosforem pochází především z povodí a podílejí se na něm různé antropogenní vlivy, zejména infrastruktura vodního hospodářství (vodovodní sítě, odkanalizování obyvatelstva, úroveň čištění odpadních vod aj.), urbanizace (nárůst nepropustných ploch v návaznosti na jednotné kanalizační systémy) a zemědělské aktivity (obdělávání půdy, hnojení, chov hospodářských zviŕat), které během posledního půlstoletí prošly výrazným vývojem, a to nejen $\checkmark$ ČR, ale i jinde v Evropě i v dalších částech světa [2-4]. Zároveň se ukazuje, že na odnos živin z povodí a jejich následný koloběh ve vodách také pưsobí změna klimatu v důsledku globálního oteplování tím, že ovlivňuje sezonnost srážek, průtoky, teplotu vody a v hlubokých jezerech a nádržích také teplotní stratifikaci [5-8].

Koncentrace $P$ je $\vee$ nádržích a jezerech řizena jednak koncentrací $P \vee$ prítocích, rychlostí jeho sedimentace a zpětného uvolňování ze sedimentu do vodního sloupce, případně recyklováním ve vodním sloupci $[9,10]$. Souhrnným výsledkem všech těchto procesů je tzv. retence P, která udává, jaká část z přísunu $P$ je $v$ nádrži zadržena. Koeficient retence $(R)$ se pak definuje jako $R=1-P / P_{\text {in, }}$ kde: $P$ je koncentrace fosforu $\vee$ nádrži, popř. $v$ odtoku, a $P$ in je př́toková koncentrace $P$. Retence $P$ je neprímo úměrná průtočnosti či hydraulickému zatížení nádrže [11, 12], ale může ji ovlivňovat také mnoho dalších faktorů, jako např. tvarová morfologie a hloubka nádrže, prítoková koncentrace $\mathrm{P}$, velikost zatížení $\mathrm{P}$, anebo nosná kapacita daného vodního tělesa pro růst fytoplanktonu [10, 13, 14], takže retence $P$ je $v$ každém vodním tělese za daného prísunu $P$ do značné míry specifická a unikátní i přes svou obecně platnou závislost na době zdržení vody nebo průtočnosti. Důsledkem je, že předpovídání retence $P$ podle průměrných vztahů sestavených na základě údajư z velkého množství morfologicky odlišných nádrží či jezer Ize provádět různými modely [10-14], ale v každém případě je zatíženo značnou nejistotou. I s tímto vědomím byl $\vee$ metodice hodnocení ekologického potenciálu nádrží RVS [15] pro nastavení hraničních limitů pro jednotlivé kategorie ekologické kvality použit průměrný model podle Vollenweidera kalibrovaný pro nádrže [10], tj. $R=1,84 \tau^{0,5} /\left(1+1,84 \tau^{0,5}\right)$, kde $\tau$ [rok] je teoretická doba zdržení vody v nádrži. Nicméně je zřejmé, že nastavené limitní hranice dobrého/středního ekologického potenciálu mohou být pro některé nádrže poměrně benevolentní, pro jiné naopak velmi přísné.

Prvotním záměrem naší studie bylo vyhodnotit př́činy změn koncentrace $P$ v časové řadě naměřené v nádrži Slapy od roku 1959 až do současnosti (tj. v řadě svou délkou a počátkem měrení unikátní minimálně v měřítcích střední Evropy) a pokusit se na jejím základě popsat vývoj zdrojů znečištění povrchových vod fosforem v povodí horní Vltavy. Brzy po zahájení analýz jsme však zjistili, že při objasňování kolísání koncentrace $\mathrm{P} \vee$ nádrži Slapy se neobejdeme bez rekonstrukce celkového vstupu P do kaskády nádrží Orlík-Kamýk-Slapy, hydrologických ukazatelů a bez charakterizace retence P v obou hlavních nádržích - Orlík a Slapy. Díky tomuto rozšiřrení studie se však podařilo sestavit ucelený datový soubor, který dokládá, že fosforové znečištění v povodí Vltavy bylo nezanedbatelné již v 60. letech minulého století a že koncentrace $P$ v nádržích Orlík a Slapy jsou do značné míry ovlivňovány nejen prísunem $P$ z povodí a hydrologií, ale také proměnlivou retencí $P \vee$ nádržích. Naše hodnocení dokumentuje jednak vývoj klíčových zdrojů znečištění P v povodí, jednak ukazuje, že v posledním čtvrtstoletí změny klimatických podmínek ovlivňují sezonní dostupnost $\mathrm{P}$ pro růst fytoplanktonu a podílejí se na zvýšené rozkolísanosti koncentrací P v letním období a na větší citlivosti nádrží k eutrofizaci.

\section{CHARAKTERISTIKA LOKALITY, POUŽITÁ DATA, METODIKA}

Povodí horní Vltavy (plocha 12968 km² k hrázi nádrže Slapy, rozsah nadmořských výšek 271-1378 m n. m.) se převážně rozkládá na území pưvodního Jihočeského kraje (tj. včetně okresu Pelhřimov), se kterým má téměř shodnou celkovou plochu i počet obyvatel, takže lze pro hodnocení socio-ekonomických ukazatelů využívat dostupná statistická krajská data. Technické charakteristiky nádrží Orlík, 


\begin{tabular}{llll} 
Charakteristika/Nádrž & Orlík & Kamýk & Slapy \\
\hline Stář́i nádrže (období napouštění) & $1960-1962$ & 1960 & $2854-1955$ \\
\hline Kóta hladiny, m n. m. & 348,1 & 6,7 & 269,3 \\
\hline Objem, mil. $\mathrm{m}^{3}$ & 569 & 1,0 & 254 \\
\hline Plocha hladiny, $\mathrm{km}^{2}$ & 21,7 & 12218 & 11,2 \\
\hline Plocha povodí, $\mathrm{km}^{2}$ & 12117 & 82,1 & 12968 \\
\hline Průměrný roční průtok, $\mathrm{m}^{3} \cdot \mathrm{s}^{-1}$ & 82,1 & 85,6 \\
\hline Průměrná doba zdržení, den & 80 & 0,9 & 34 \\
\hline Maximální/průměrná hloubka, $\mathrm{m}$ & $74 / 26$ & $14 / 7$ & $58 / 23$
\end{tabular}

Kamýk a Slapy jsou uvedeny v tabulce 1. Z limnologického hlediska Orlík patři ke zvrstveným dimiktickým nádržím vytvářejícím letní i zimní stratifikaci. Kamýk je silně průtočná nestratifikovaná nádrž. Slapy jsou zvrstvená monomiktická nádrž, která v zimě nezamrzá a v době letní stratifikace se vyznačuje výrazným zkratováním prítoku hypolimniem, protože relativně chladná voda vypouštěná z hypolimnia nádrže Orlík se ve Slapech zasunuje do spodních vrstev, odkud je odtahována na turbíny hydroelektrárny výpustmi v hloubce cca 40 m.

Pro charakterizaci kvality vody byla použita: (i) Data z dlouhodobého sledování nádrže Slapy Hydrobiologickým ústavem Biologického centra AV ČR, v. v. i. (HBÚ), které probíhalo nepřetržitě od r. 1959 v třítýdenních intervalech v profilu Nebřich (nad Živohošťským mostem) a po dobu omezených časových úseků také na prítoku do nádrže (VItava - Kamýk nad Vlt.) a na odtoku (VN Slapy - výtok). Po celou dobu sledování byl analyzován celkový fosfor $\left(\mathrm{P}_{\text {celk }}\right)$ citlivou limnologickou metodou (s mezí stanovitelnosti $0,003 \mathrm{mg} \cdot \cdot^{-1}$ ) po mineralizaci s kyselinou chloristou [16-18]. (ii) Data z provozního sledování jakosti povrchových vod prováděného podnikem Povodí VItavy, státní podnik (PVL) a jeho předchůdci od r. 1963 v měsíčních intervalech v profilech Vltava - Týn n/Vlt., Lužnice - Koloděje (popř. od r. 2013 Bechyně), Otava - Písek, Lomnice - Dolní Ostrovec, Skalice - Varvažov, VN Orlík - hráz, VItava - Solenice (výtok VN Orlík; od r. 1972), Mastník - Radíč (od r. 2011), VN Slapy - hráz a VN Štěchovice - hráz (od r. 1979). Koncentrace $P_{\text {celk }}$ se $v$ těchto datových řadách začaly analyzovat až počínaje rokem 1990. $V$ drívějším období byla data $P_{\text {celk }}$ zrekonstruována jako součet jejích dílčích složek, tj. $\mathrm{P}_{\text {celk }}=\mathrm{PO}_{4}-\mathrm{P}+\mathrm{RNP}+\mathrm{PP}$, kde: $\mathrm{PO}_{4}-\mathrm{P}$ je ortofosforečnanový $P$, který byl prímo analyzován od r. 1972 jako rozpuštěný reaktivní $P$ a v předchozích letech byl dopočten z regresních závislostí na průtoku, popř. také na teplotě vody, kalibrovaných pro každý jednotlivý profil; RNP je rozpuštěný nereaktivní $\mathrm{P}$, který byl vypočten z koncentrace $\mathrm{CHSK}_{\mathrm{Mn}}$ pomocí regresní rovnice RNP $\left[\mathrm{mg} \cdot \cdot^{-1}\right]=0,0015 \times \mathrm{CHSK}_{\mathrm{Mn}}\left[\mathrm{mg} \cdot \mathrm{l}^{-1}\right]$ získané pro toky $\vee$ povodí Malše, jejíz platnost byla ale ověřena také na několikaletých datech pro nádrž Orlík (profil hráz, 1990-1991) a Slapy-Nebřich (1998-2016) (Hejzlar, nepublikovaná data); a PP je nerozpuštěný (partikulovaný) fosfor, který byl vypočten z regresních vztahů na koncentraci sušiny nerozpuštěných látek (NL105), popř. také ztrátě žíháním (NL550), kalibrovaných pro jednotlivé profily. Pro hodnocení dlouhodobých koncentračních trendů statistickými metodami byly pro všechny lokality vypočteny měsíční průměry. Pro hodnocení splnění/překročení limitů pro dobrý ekologický potenciál podle RVS [15] byly v profilech nádrží VN Orlík hráz a Slapy - Nebřich vypočteny průměrné hodnoty za období duben až říjen.

Denní průtoková data v přítocích do nádrže Orlík pocházejí z měření na limnigrafických stanicích Českého hydrometeorologickém ústavu (ČHMÚ) VItava Hluboká n/VIt., popř. Vltava - České Budějovice (po r. 1990), Lužnice - Bechyně,
Otava - Písek, Lomnice - Dolní Ostrovec, Skalice - Varvažov; prítok do nádrží z neměřeného zbytku povodí včetně průtoku $v$ profilu Mastník - Radíč byl vypočten hydrologickou analogií na základě průměrného odtoku z povodí Lomnice a Skalice. Údaje o kótách hladiny, odběrech hydroelektráren a celkovém odtoku byly získány z písemných hodinových záznamů, popř. po roce 1990 z elektronické databáze archívu provozního sledování Vltavské kaskády v pražském centrálním vodohospodářském dispečinku PVL. Odtok z nádrží byl následně zrekonstruován metodou bilancování množství přitékající vody a aktuálních změn objemu vody v nádržích s krokem 1 hodina. Dlouhodobá denní klimatická data v měřících stanicích Tábor a České Budějovice pochází z databáze ČHMÚ.

Bilanční výpočty ročního množství P přinášeného do nádrží př́itoky a množství $P$ odtékajícího z nádrží byly prováděny v měsíčním kroku vynásobením průměrného měsíčního průtoku a průměrné koncentrace $P z$ dat naměřených $\checkmark$ daném měsíci a sumací do ročních hodnot. Z celkového ročního množství $P$ a množství vody proteklé $v$ daném profilu pak byla vypočtena průtokově vážená průměrná koncentrace. Do vstupu $P$ do nádrže byla zahrnuta rovněž atmosférická depozice na základě měření množství a složení srážek na nádrži Slapy v profilu Nebřich Hydrobiologickým ústavem BC AV ČR. Průměrná roční hodnota depozice $P_{\text {celk }} \vee$ období 1979-2015 byla $9 \pm 2 \mathrm{mg} \cdot \mathrm{m}^{-2}$, což představuje z hlediska celkového zatížení nádrže fosforem nevýznamné množství, tj. $<1 \%$.

Socioekonomické ukazatele charakterizující růst populace, zemědělské aktivity a vývoj komunální infrastruktury pocházejí ze statistických ročenek Českého statistického úradu pro Jihočeský kraj.

Retence P v nádržích byla hodnocena pomocí empirického modelu založeného na vztahu retence živin a hydrauliky nádrže podle Chapra [12]. Model používá základní rovnici s definováním retence $R: P_{0}=P_{\text {in }}(1-R)$, kde $P_{0}$ je prưměrná roční koncentrace $P \vee$ odtoku z nádrže; $P$ in je objemově vážená koncentrace $P$ $\checkmark$ celkovém prítoku do nádrže, tj. podíl látkového množství $P$ vstupujícího do nádrže ze všech zdrojů (přitoky, atmosférická depozice atd.) a celkového vstupu vody do nádrže. $V$ tomto modelu je retence závislá na hydraulickém zatížení podle vzorce: $R=v_{p} /\left(v_{p}+q_{w}\right), k d e v_{p}\left[m \cdot a^{-1}\right]$ je součinitel sedimentační rychlosti $P$ $\checkmark$ nádrži (součinitel reakce 1. rádu pro retenci $P$ ) a $q_{w}\left[\mathrm{~m}^{-1}\right]$ je hydraulické zatížení nádrže vztažené na plochu její hladiny. Hodnoty $v_{p}$ byly vypočteny pro nádrže Orlík a Slapy z naměřených dat $P_{o^{\prime}} P_{\text {in }}$ a $\mathrm{q}_{w}$ pomocí vztahu vzniklého spojením a úpravou dvou výše uvedených rovnic: $v_{p}=q_{w}\left(P_{\text {in }}-P_{o}\right) / P_{0}$. 

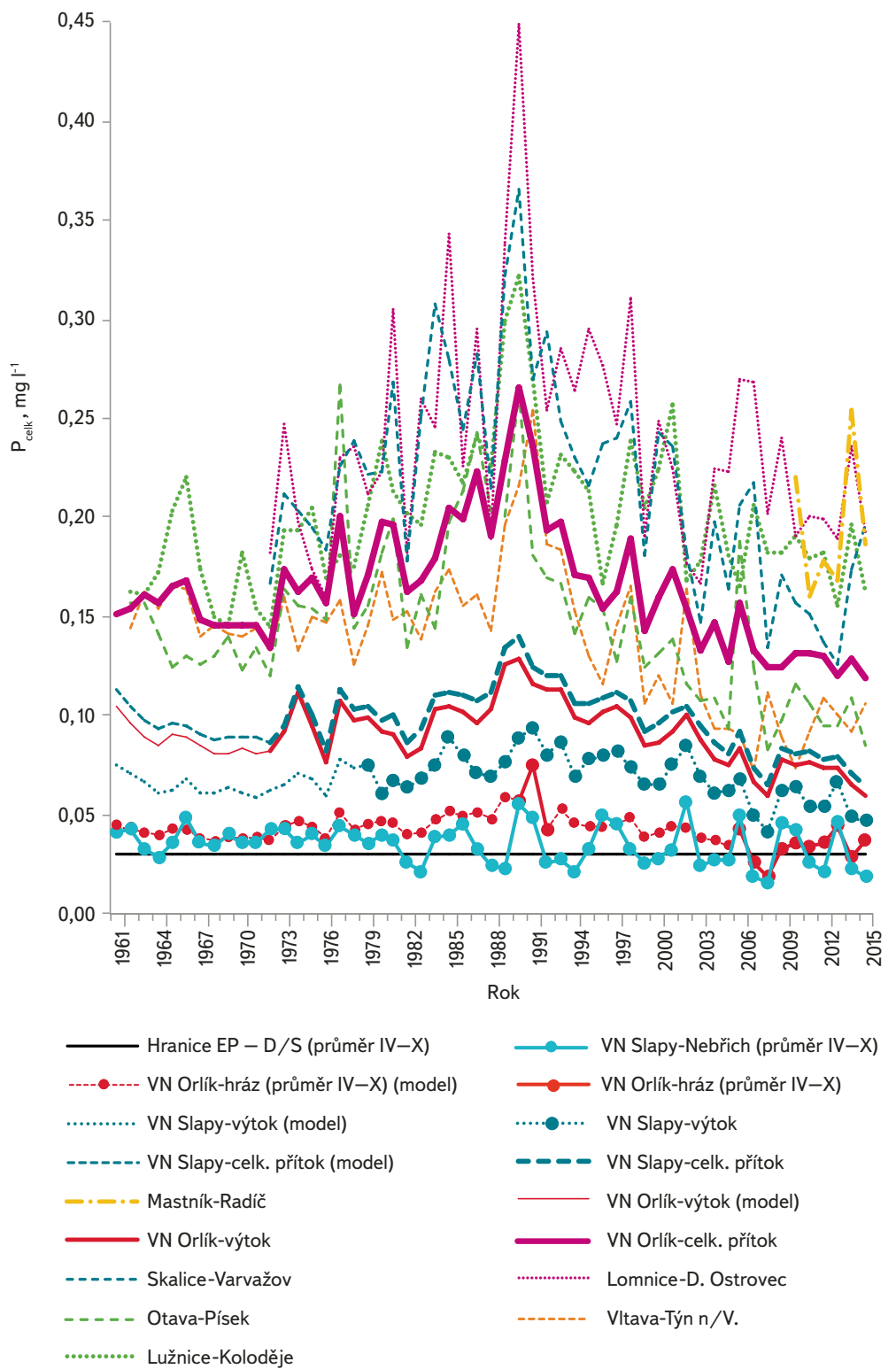

Obr. 1. Průtokově vážené průměrné roční koncentrace $P_{\text {celk }} \vee$ nádržich Orlík a Slapy a v jejich prítocích a odtocích v období 1961-2015, s vyznačením hranice mezi dobrým a středním ekologickým potenciálem RVS $\left(0,03 \mathrm{mg} \cdot \mathrm{l}^{-1}\right.$ shodně pro obě nádrže) Fig. 1. Flow-weighted average annual concentrations of total P in Orlík and Slapy reservoirs and their tributaries in the period 1961-2015, indicating the boundary between the good and moderate ecological potential of EU WFD $\left(0.03 \mathrm{mg} \cdot \mathrm{l}^{-1}\right.$ for both reservoirs)

Statistické metody použité pro analýzu datových řad zahrnovaly zejména: (i) sezonní Kendallův test [19], což je neparametrická metoda pro detekci monotónních trendů; (ii) lineární regresní analýzu a korelační analýzu (MS Excel 2010) pro hodnocení vztahů mezi veličinami; (iii) segmentovou regresní analýzu [20], která byla využívána pro detekci zlomových bodů v datových řadách (program SegReg vyvinutý v Institute for Land Reclamation and Improvement, Nizozemsko; http://www.waterlog.info/segreg.htm). Všechny statistické testy byly prováděny na hladině významnosti $a=0,05$.
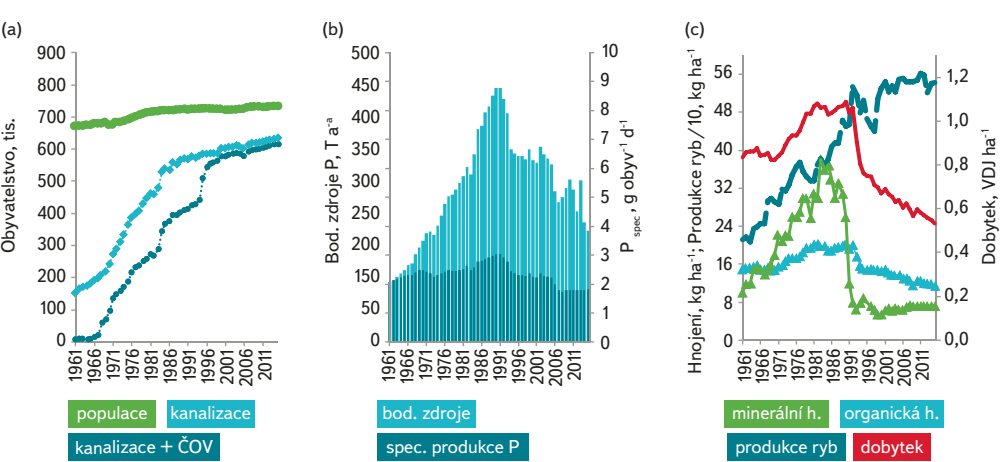

Obr. 2. Vývoj socio-ekonomických ukazatelů v povodí nádrže Slapy: (a) celkový počet obyvatel, populace připojená ke kanalizaci a ke kanalizaci s ČOV; (b) export P z bodových zdrojů do povrchových vod a specifická produkce P obyvatelstvem do odpadních $\operatorname{vod}\left(P_{\text {spec }}\right) ;(c)$ aplikace $P \vee$ hnojivech, hustota dobytka na zemědělské půdě a intenzita rybničního chovu ryb

Fig. 2. Development of socio-economic indicators in the Slapy catchment: (a) total population (populace celkem), population connected to sewerage (kanalizace) and sewerage with WWTP (kanalizace + ČOV); (b) export of P from point source to surface water and specific $\mathrm{P}$ production by population to wastewater $\left(\mathrm{P}_{\text {spec }}\right) ;(\mathrm{c}) \mathrm{P}$ application in fertilizers, livestock density on farmland, and intensity of fish pond production

\section{TRENDY VÝVOJE KONCENTRACÍ P}

Průtokově vážené průměrné roční koncentrace $P_{\text {celk }} \vee$ nádržích Orlík, Slapy i v jejich prítocích (obr. 1) měly během období 1961-2015 charakteristický průběh s postupným nárůstem vrcholícím na přelomu 80. a 90. let minulého století, rychlým poklesem do roku 2005 a pak s poměrně vyrovnanými hodnotami. Nejvýraznější nárůst ( $\mathrm{z}$ hodnot kolem $0,15 \mathrm{mg} \cdot \mathrm{l}^{-1}$ - cca do roku 1975), vrchol (0,25 mg.l-1 $v$ letech 1989-1990) a pokles (na cca 0,13 mg.l-1 od roku 2007) měly koncentrace $P_{\text {celk }} v$ celkovém prítoku do nádrže Orlík, což bylo výsledkem kombinace trendů $\vee$ dílčich prítocích, z nichž průtokově nejvýznamnější je Vltava přivádějící do nádrže 35 \% vody a dále Otava (30 \%) s Lužnicí (28 \%), kdežto ostatní př́toky jsou relativně malé (Lomnice $2 \%$; Skalice $2 \%$, zbytek povodí $3 \%$ ). Z hlavních př́toků přinášela do nádrže Orlík nejvyšší koncentrace $P_{\text {celk }}$ Lužnice, u níž byl ve srovnání s VItavou i Otavou pokles v posledních cca 30 letech relativně i absolutně nejnižší. $V$ nádrži Orlík se prítoková koncentrace $P_{\text {celk }}$ výrazně snižovala a v odtoku byla přibližně poloviční. Celkový prítok do nádrže Slapy byl oproti odtoku z nádrže Orlík mírně navýšen v důsledku znečištěných bočních prítoků, reprezentovaných $v$ naší studii nejvodnějším z nich, potokem Mastník (přivádí do nádrže Slapy 55 \% vody bočních př́toků, či 1,5 \% celkového prítoku). Koncentrace $P_{\text {celk }}$ se $v$ nádrži Slapy snižovala sedimentačními procesy zhruba o 30 \% na rozmezí 0,065-0,09 mg.|l-1. Prüměrné koncentrace $P_{\text {celk }}$ během vegetačního období (duben-říjen) v hladinové vrstvě, jež se používají při hodnocení ekologického potenciálu RVS, byly výrazně nižší než odtokové koncentrace, což je typické pro stratifikované nádrže se spodním vypouštěním, které způsobuje zkratování prítoku hypolimniem a jeho omezené promíchávání s hladinovou vrstvou. V posledních dekádách tyto koncentrace $v$ nádrži Slapy kolísaly kolem limitní hranice pro dobrý ekologický potenciál 0,03 mg.l-1 (jež je shodná pro nádrž Slapy i Orlík [15]), kdežto v nádrži Orlík byly tyto koncentrace až na výjimky vyšší (obr. 1). 


\section{TRENDY SOCIOEKONOMICKÝCH UKAZATELU゚ V POVODÍ}

Socio-ekonomické ukazatele se $v$ povodí nádrže Slapy během posledního půlstoletí výrazně vyvíjely, s největšími změnami zhruba do poloviny 90 . let minulého století (obr. 2). Počet obyvatel se zvětšoval jen mírně, ale zásadně se měnila velikost populace připojené na kanalizaci a čistírny odpadních vod (obr. 2a), jako i účinnosti ČOV z hlediska odstraňování P. Výraznými změnami prošla také specifická produkce $P$ obyvatelstvem do komunálních odpadních vod (obr. 2b), která až do počátku 90. let rostla v důsledku zvyšování použití fosfátových detergentů a poté klesla ve dvou vlnách - po uzavření dohody Ministerstva životního prostředí ČR s výrobci detergentů o omezení koncentrace fosforu $v$ detergentech $v$ roce 1995 a úplném legislativním zákazu fosfátových detergentů $\vee$ maloobchodním prodeji v roce 2006. Výsledkem těchto změn byl dramatický vývoj $\vee$ množství $P$ ve vypouštěných odpadních vodách (obr. 2b), které od 60. do 90. let minulého století postupně narůstalo až na více než čtyřnásobek, ale pak nastal obrat a množství vypouštěného $P$ začalo počátkem 90. let klesat po provedených intenzifikacích větších ČOV (nad 10000 EO), které byly vybavovány technologiemi pro zvýšené odstraňování P. V zemědělském sektoru se zvyšovaly do konce 80 . let aplikace $P \vee$ minerálních hnojivech z 10 na $37 \mathrm{~kg} \cdot \mathrm{ha}^{-1}$ a v organických hnojivech z 15 na $20 \mathrm{~kg} \cdot \mathrm{ha}^{-1}$, ale pak nastal jejich výrazný pokles. Intenzita roční produkce rybničního chovu ryb vzrostla z počáteční hodnoty cca $230 \mathrm{~kg} \cdot h a^{-1} \mathrm{na}>500 \mathrm{~kg} \cdot h \mathrm{~h}^{-1} \mathrm{v} 90$. letech a do konce sledovaného období se udržovala na této úrovni (obr.2c).

Korelační analýza prokázala pro celkové období 1961-2015 statisticky významné pozitivní vztahy mezi roční průměrnou koncentrací $P_{\text {celk }} \vee$ přítoku do nádrže Orlík a zatížením P z odpadních vod, specifickou produkcí P obyvatelstva do odpadních vod a hnojením organickými i minerálními hnojivy, tj. se všemi ukazateli s maximem na přelomu 80. a 90. let minulého století (tabulka 2). Pro dílči období před a do roku 1991 byly zjištěny významné korelace také pro podíly připojených obyvatel na kanalizaci i na kanalizaci s ČOV a pro velikost produkce chovu ryb. V období 1961-1990 byly korelace s těmito ukazateli pozitivní, kdežto v období 1991-2015 negativní, což znamená, že význam a podíl těchto dílčích ukazatelů z hlediska celkových zdrojů $\mathrm{P} v$ povodí z kvantitativního hlediska nebyl rozhodující. Korelační analýza nedokáže jednoznačně rozlišit míru vlivu jednotlivých autokorelovaných veličin, což je případ většiny veličin zahrnutých do této analýzy, nicméně i tak Ize z výsledků udělat jednoznačný závěr o tom, že jak bodové zdroje P, tj. vypouštění komunálních odpadních vod, tak difúzní zdroje $P$, tj. zemědělské hospodaření, popř. také s rybářstvím, jsou hlavními přispěvateli ke znečištění nádrží Orlík a Slapy fosforem. K zodpovězení otázky, který z těchto dvou typů zdrojů kvantitativně převažoval, by však bylo třeba mnohem podrobnějšího rozboru časových raad odnosu P z dílčích subpovodí, zejména s vyhodnocením závislostí odnosu na průtoku a velikosti dočasné i trvalé retence $P$ v říční síti, rybnících a jiných nádržích.

\section{RETENCE FOSFORU V NÁDRŽíCH}

Relativní množství zadrženého $P$ (neboli koeficient retence $R$ ) v nádrži Orlík v letech 1972-2015, pro něž se nám podařilo zrekonstruovat př́tokové i odtokové koncentrace, kolísalo $v$ rozmezí od 0,31 do 0,58 s průměrem ( \pm směrodatnou odchylkou) 0,44 \pm 0,06 a bylo zhruba o polovinu vyšší než byla hodnota $R$ v nádrži Slapy, tj. průměr 0,30 \pm 0,05 pro období 1979-2015 (obr. 3a). Hodnoty R byly nejvyšší v 80. letech s mírnou (statisticky nevýznamnou) tendencí k poklesu $\checkmark$ pozdějších letech. Odlišnosti v retenci $R$ mezi oběma nádržemi i meziroční variabilitu R Ize připsat na vrub hlavně rozdílům doby zdržení vody v nádržích a meziročnímu kolísání průtoků, protože součinitel sedimentační rychlosti $v_{p}$ nabýval v obou nádržích srovnatelných průměrných hodnot, tj. $95 \pm 33 \mathrm{~m} \cdot \mathrm{a}^{-1}$ v nádrži Orlík a $105 \pm 36 \mathrm{~m} \cdot \mathrm{a}^{-1}$ v nádrži Slapy. Změny $v_{p}$ v průběhu sledovaného období probíhaly $\vee$ obou nádržích víceméně souběžně (obr. 3b), takže mezi jejich ročními hodnotami v byl silný korelační vztah, vysvětlující 52 \% variability (obr. 3c). Príčiny variability hodnot $v_{p}$ jsme testovali pomocí korelační analýzy a vícenásobné lineární regresní analýzy a hledali jsme souvislosti např. s koncentracemi a složením forem $P \vee$ prítocích do nádrží, průtokem, teplotou vody či klimatickými veličinami. Jako jediná statisticky významná příčina byla nalezena pozitivní závislost $v_{p}$ na absolutní velikosti přísunu $\mathrm{P}$ do nádrže, která se ale lišila ve velikosti směrnice $v$ obdobích pred rokem 1990 a v období 1991-2015 (obr. 3d, e). Do roku 1990, tj. období rostoucího odnosu P z povodí, dokázala tato závislost vysvětlit u obou nádrží přes 70 \% variability a její směrnice byla strmější než od roku 1991, kdy prísun P z povodí postupně klesal a vztah mezi v a přísunem P do nádrží byl volnější, s vysvětlenou variabilitou 37 \%. Toto zjištění je zajímavé, protože nabízí vysvětlení, proč koncentrace P v nádržích neklesaly

Tabulka 2. Korelační vztahy mezi roční prüměrnou koncentrací P celk v celkovém př́toku do nádrže Orlík a ročními hodnotami socio-ekonomických ukazatelů v povodí (Bod. z. P bodové zdroje P v povodí; $P_{\text {spec }}$ - specifická produkce P obyvatelstvem do komunálních odpadních vod; $X_{K}$ - podíl obyvatel pripojených na kanalizaci; $X_{\check{c o v}}$ - podíl obyvatel připojených na kanalizaci s ČOV; Hnoj. org. - hnojení Pvorganických hnojivech; Hnoj. min. - hnojení Pv minerálních hnojivech; Dobytek - hustota dobytka na zemědělské půdě; Chov ryb - ročni produkce rybničního chovu ryb) pro rưzná časová období

Table 2. Correlation between the annual average concentration of total $P$ in the total inflow into the Orlik reservoir and the annual values of socio-economic indicators in the catchment (Bod. z. $P$ - point sources of $P$ in catchment; $P_{\text {spec }}$ - specific $P$ production by population to wastewater; $X_{K}-$ proportion of population connected to sewerage; $X_{\check{c} \text { cov }}-$ proportion of population connected to sewerage with WWTP; Hnoj.org. - fertilisation of farmland with manure; Hnoj. min. - mineral fertilisers; Dobytek - livestock on farmland; Chov ryb - annual fish pond production) in different time periods

\section{Koncentrace}

Socio-ekonomické ukazatele $§$

\begin{tabular}{|c|c|c|c|c|c|c|c|}
\hline $\mathbf{P}_{\text {celk }} \mathbf{v}$ období & Bod.z. P & $\mathbf{P}_{\text {spec }}$ & $\mathrm{x}_{\mathrm{K}}$ & $X_{\text {čov }}$ & Hnoj. org. & Hnoj. min. & Chov ryb \\
\hline 1961-2015 & $0,57^{* *}$ & $0,84^{* *}$ & 0,04 & $(-) 0,15$ & $0,80^{* *}$ & $0,53^{* *}$ & $(-) 0,16$ \\
\hline 1961-1990 & $0,81^{* *}$ & $0,78^{* *}$ & $0,74^{* *}$ & $0,75^{* *}$ & $0,70^{* *}$ & $0,53^{* *}$ & $0,71^{* *}$ \\
\hline 1991-2015 & $0,83^{* *}$ & $0,88^{* *}$ & $(-) 0,86^{* *}$ & $(-) 0,50^{* *}$ & $0,90^{* *}$ & $0,50^{*}$ & $(-) 0,63^{* *}$ \\
\hline
\end{tabular}

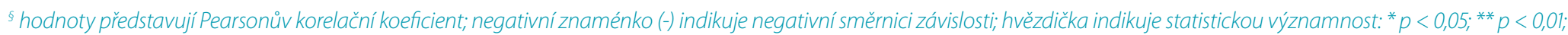
statisticky významné hodnoty jsou tučným písmem

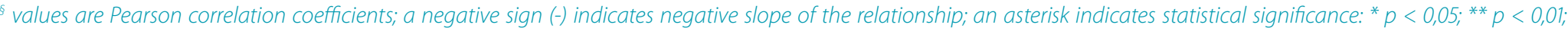
statistically significant values are in bold 
úměrně snižování jejich prítokových koncentrací. Kromě toho, extrapolace $v_{p}$ $\checkmark$ regresní rovnici do nulové hodnoty umožňuje odhadnout, jak se sediment meziročně podílel na snižování či zvyšování zatížení nádrže fosforem. V období do roku 1990 jsou pro obě nádrže úseky na ose x (přísun P do nádrže) vytínané regresní prímkou kladné, takže sediment byl tehdy schopen $P$ vázat cca desítky t P za rok, kdežto po roce 1991 jsou tyto úseky záporné, což indikuje naopak velkou pravděpodobnost uvolňování P ze sedimentu. Do roku 1990, kdy rostl prísun $P$ z povodí, se zjevně vytvářela v sedimentech nádrží zásoba $P$, ze které se $v$ dalším období snižování prísunu P do nádrží fosfor postupně uvolňuje a tlumí pokles koncentrace ve vodním sloupci. Popsaná situace není pro nádrže ojedinělá. Vliv vnitřního zatížení $P$ ze sedimentů na koncentrace $P$ a na zbrzd’ování jejich poklesu po snižení externího zatižení $\mathrm{P}$ z povodí byl prokázán v řadě studií - např. u německé nádrže Wahnbach [21] nebo u severoamerických [22-24] či afrických [25] nádrží značný potenciál k uvolňování P ze sedimentů v jihomoravské nádrži Vranov ukázali Jan a kol. [26]. Pro dosažení limitní koncentrace pro dobrý ekologický potenciál v nádržích Orlík i Slapy je tedy potřeba počítat s vyšším rozsahem opatření ke snižení odnosu P v povodí, než jak by se dalo předpokládat na základě velikosti retence $v$ době $s$ nejvyšším znečištěním.

\section{DLOUHODOBÁ A SEZONNÍ VARIABILITA KONCENTRACE P V NÁDRŽI SLAPY}

Jednotlivé koncentrace $P_{\text {celk }}$ naměřené $v$ nádrži Slapy $v$ profilu Nebřich během nepřetržitého 57letého sledování se pohybovaly v řádovém rozmezí 0,010-0,120 mg $\left.\right|^{-1}$ a průměrné roční koncentrace $v$ rozmezí 0,031-0,077 mg $\left.\right|^{-1}$ (obr. 4). Pro celé období (1961-2015) Kendallův test neprokázal žádné statisticky významné monotónní trendy ani pro průměrné roční, ani pro sezonní
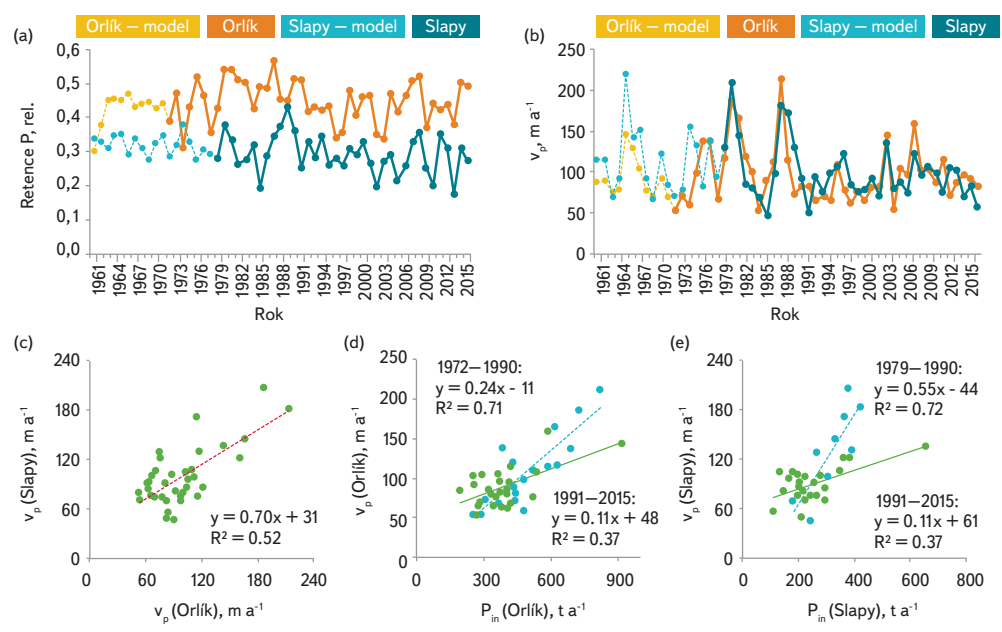

Obr. 3. Ukazatele retence $P \vee$ nádržích Orlík a Slapy: (a) relativní retence vypočtená z celkového zatížení a odtokové koncentrace $P$; (b) součinitel sedimentační rychlosti $v_{p} ;(c)$ korelační vztah mezi ročními hodnotami v v nádržích Orlík a Slapy; (d) závislost v v nádrži Orlík na prísunu P v období nárůstu zatížení (1972-1990) a v období jeho poklesu (1991-2015); (e) závislost v v v nádrži Slapy na přísunu P v období nárůstu zatížení (1979-1990) a v období jeho poklesu (1991-2015)

Fig. 3. Indicators of P retention in reservoirs Orlík and Slapy: (a) relative retention calculated from the total load and outflow concentration of $P$; (b) coefficient of $P$ settling rate $V_{p i}(c)$ correlation between annual values of $v_{p}$ in reservoirs Orlík and Slapy; (d) dependence of $v_{p}$ in the Orlík reservoir on the P-load during the period of increase of the load (1972-1990) and during the period of its decline (1991-2015); (e) dependence of $v_{p}$ in the Slapy reservoir on the P-load during the period of increase of the load (1979-1990) and during the period of its decline (1991-2015)

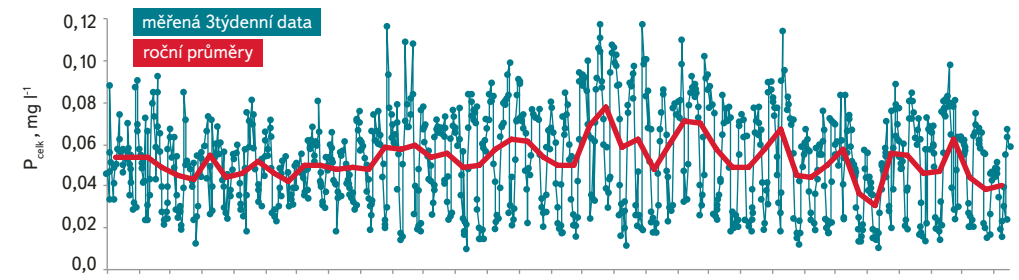

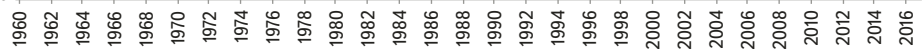
Rok

Obr. 4. Koncetrace $P_{\text {celk }}$ v profilu Slapy-Nebřich v období 1960-2016

Fig. 4. Concentration of total $P$ in the Slapy-Nebrich profile in the period 1960-2016 (black line with points - measured data in 3 week intervals; red line - annual averages)

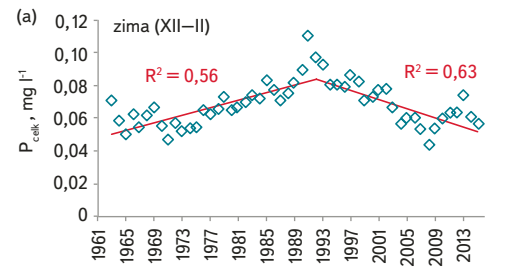

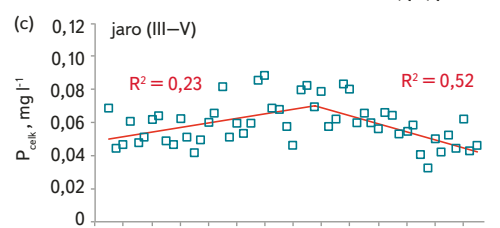

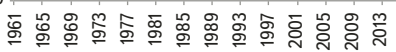

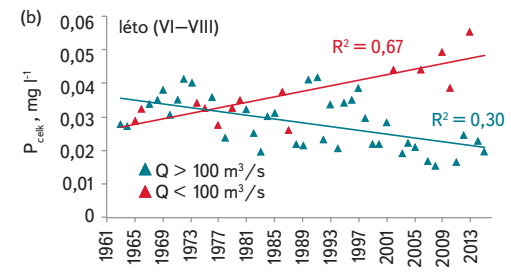

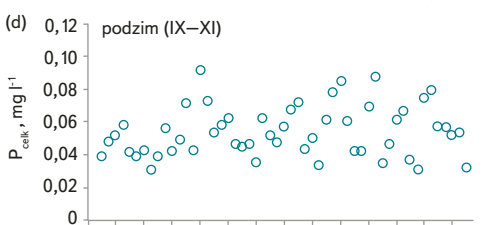

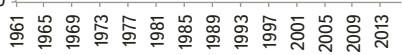

Obr. 5. Časové řady prưměrných sezonních koncentrací $P_{\text {celk }} \vee$ nádrži Slapy; čáry ukazují statisticky významné $(p<0,05)$ lineární regresní trendy

Fig. 5. Time series of average seasonal concentrations of total $P$ in the Slapy reservoir; the lines show statistically significant $(p<0.05)$ linear regression trends

koncentrace $P_{\text {celk }}$. Použití segmentové regrese ale prokázalo v roce 1992 pro roční koncentrace $P_{\text {celk }}$ zlomový bod, který rozdělil časovou řadu na dva úseky se statisticky významnými trendy v období 1961-1991 s trendem nárůstu 0,6 $\mathrm{gg} \mathrm{I}^{-1} \cdot \mathrm{a}^{-1}$ a v období 1992-2015 s trendem poklesu -0,9 $\mu \mathrm{g} \mathrm{I}^{-1} \cdot \mathrm{a}^{-1}$.

Sezonní koncentrace $P_{\text {celk }}$ byly nejnižší v letním a nejvyšší v zimním období (obr. 5). V časových řadách zimních a jarních koncentrací byl segmentovou regresí zjištěn, obdobně jako pro roční koncentrace, zlomový bod v roce 1992 s rostoucím trendem v období 1961-1991 a klesajícím trendem v období 1992-2015 (obr. 5a, c). Letní a podzimní koncentrace byly rozptýlené a žádné časové trendy u nich prokazatelné nebyly. Nicméně, ve variabilitě letních koncentrací byly identifikovány dva protichůdné časové trendy při průměrném průtoku nad a pod $100 \mathrm{~m}^{3} \cdot \mathrm{s}^{-1}$, tj. s poklesem koncentrací $P_{\text {celk }}$ při průtoku $<100 \mathrm{~m}^{3} \cdot \mathrm{s}^{-1}$ a s jejich nárůstem při průtoku $>100 \mathrm{~m}^{3} \cdot \mathrm{s}^{-1}$ (obr. 5c). Regresní analýza vztahu letních koncentrací $P_{\text {celk }}$ a průtoku pro dvě období (1963-1991 a 1992-2015) ukázala, že koncentrace $P_{\text {celk }}$ byly do roku 1991 na průtoku nezávislé, kdežto po roce 1991 se při zvýšeném průtoku začaly výrazně zvyšovat (obr. 6). Pro podzimní období vzhledem k velkému rozptylu dat žádné trendy ani závislosti zjištěny nebyly.

\section{TRENDY ENVIRONMENTÁLNÍCH VELIČIN}

Změny klimatických a hydrologických podmínek na Slapské nádrži od roku 1961 jsou ukázány na obr. 7.

Hladinová teplota vody naměrená při tř́týdenních odběrech začala růst koncem 80. let minulého století a zvýšila se do současnosti v průměru o cca $1,5^{\circ} \mathrm{C}$ (obr. 7a). Sezonní Kendallův test prokázal statisticky významný $(p<0,01)$ trend nárůstu se směrnicí $0,03^{\circ} \mathrm{C} a^{-1}$ za celé období či $0,08^{\circ} \mathrm{C} a^{-1} \vee$ období 1987-2015. 


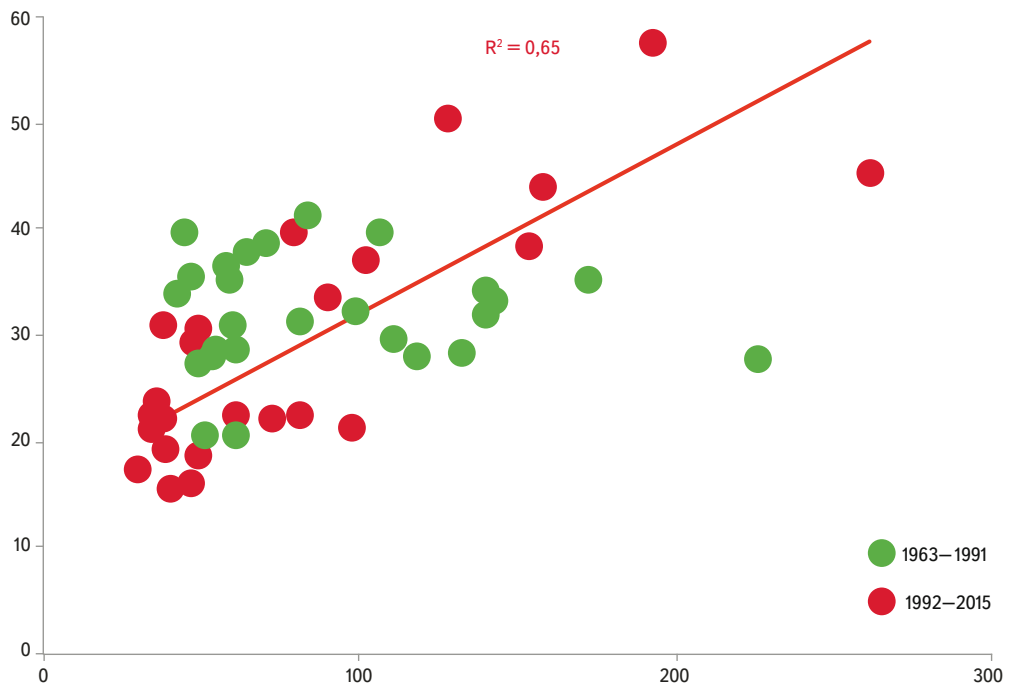

Obr. 6. Regresní vztahy mezi průměrnou koncentrací $P_{\text {celk }}$ a průtokem v nádrži Slapy v letních měsících (VI-VIII) ve dvou obdobích: 1963-1991 and 1992-2015

Fig. 6. Regression relations between the average concentration of total $\mathrm{P}$ and the flow in the Slapy reservoir in the summer months (VI-VIII) in two periods: 1963-1991 and 1992-2015

Významné rostoucí trendy teploty vody byly prokázány $v$ posledních letech i pro všechny čtyři roční sezony, pričemž zlomový bod počátku teplotního nárůstu u nich segmentová regrese našla v rozmezí let 1987-1990. Velmi podobné změny $v$ teplotě vody byly popsány $u$ řady evropských jezer, např. $\checkmark$ Bodamském jezeře $v$ Německu [27], ve švýcarských jezerech [28] či ve Švédsku [29] a jsou připisovány globální klimatické změně [28-30].

Pro průměrné roční či sezonní průtoky v nádrži Slapy jsme Kendallovým testem nebo segmentovou regresí nenašli žádné statisticky významné trendy nebo zlomové body. Nicméně, u průměrných měsíčních průtoků jsme zjistili, že rozdělení jejich hodnot bylo odlišné v období 1961-1990 a 1991-2015 (obr. 7b,c), přičemž v období 1991-2015 byly průtoky nevyrovnanější, na jedné straně s vyššši frekvencí nižších průtoků, na druhé straně s větším počtem extrémně vysokých hodnot. Události s extrémně vysokými průtoky v období 1991-2015 se vyskytovaly především v letním, popř. v pozdně jarním období.

\section{ZÁVĚR}

Analýza dlouhodobých dat koncentrací $P_{\text {celk }} \vee$ nádržích Orlík a Slapy ukázala zřetelnou souvislost $s$ různými fázemi socio-ekonomického vývoje $v$ povodí a se změnami klimatických a hydrologických podmínek. Rostoucí a klesající trendy koncentrací a bilance $\mathrm{P} \vee$ prítoku do nádrží i v nádržích samotných $\vee$ obdobích 1961-1990 a 1991-2015 odpovídaly změnám zdrojů znečištění v povodí, tj. zejména zatízení povrchových vod fosforem z komunálních odpadních vod a zemědělství. Při snižování zatížení povrchových vod fosforem v období 1991-2015 hrály velkou roli změny v ekonomice a environmentální legislativě ČR. Analýza retence $P \vee$ nádržích ukázala, že $P$ akumulovaný $v$ sedimentech nádrže $v$ době rostoucího zatížení P z povodí v období 1961-1990 se v následujícím období poklesu zatižení $P$ začal uvolňovat a zpětně obohacuje koncentraci $P_{\text {celk }}$ ve vodním sloupci a tlumí vliv poklesu koncentrací $\mathrm{P} \vee$ prítoku do nádrží.

$\checkmark$ prípadě hladinové koncentrace $P_{\text {celk }} \vee$ nádrži Slapy v letním období byly príčiny dlouhodobé variability komplexnější a kromě změn zatížení $P$ z povodí závisely také na klimatických a hydrologických podmínkách, tj. hlavně nárůstu teploty a zvětšování nerovnoměrnosti průtoku. Nízký průtok podporuje v nádrži Slapy prodlužování doby stratifikace a pokles koncentrace P v povrchové vrstvě. Naopak
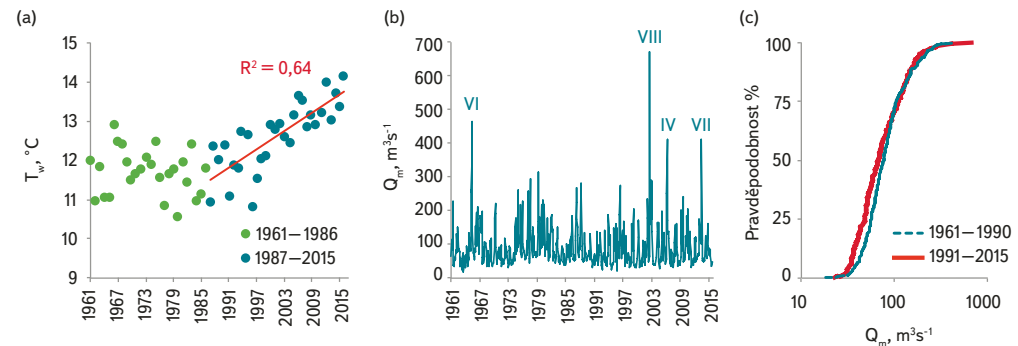

Obr. 7. Ukazatele klimatických a hydrologických podmínek v nádrži Slapy během 1961-2015: (a) časová řada průměrných ročních teplot vody v hladinové vrstvě s odlišeným obdobím 1987-2015, kdy byl prokázán rostoucí trend; (b) průměrný měsíční prítok (s vyznačením extrémních měsíců); (c) kumulativní distribuční funkce průtoku v obdobích 1961-1990 a 1991-2015

Fig. 7. Indicators of climatic and hydrological conditions in the Slapy reservoir during 1961-2015: (a) time series of average annual surface water temperatures with a distinguished period 1987-2015 when a growing trend has been proven; (b) average monthly inflow (with the indication of extreme months); (c) the cumulative distribution function of the flow in periods 1961-1990 and 1991-2015

události s vysokým průtokem způsobují i v letním období narušení stratifikace, promíchávání hlubokých vrstev vody (z hypolimnia bohatého na P, jednak díky vysokým prítokových koncentracím, a také v důsledku uvolňování P ze sedimentů) s epilimniem a zvyšování koncentrace P. Proto se variabilita letních koncentrací P v nádrži začala po roce 1990 zvyšovat a stala se závislou na průtoku. Tento mechanismus vede paradoxně k situaci, kdy letní koncentrace $P_{\text {celk }} \vee$ epilimniu mohou při vysokém průtoku růst (a eutrofizovat nádrž více než v minulosti) navzdory obecnému poklesu zatížení P i poklesu zimních a jarních koncentrací $P_{\text {celk. }}$.

Naše výsledky ukazují, že změna klimatu může vést $k$ větší citlivosti vodního ekosystému nádrží vưči př́sunu živin a může způsobovat zvyšování jejich eutrofizace i při stabilním nebo klesajícím vnějším zatížení P. Tato skutečnost vyzdvihuje nutnost dalšího snižování vnějších zdrojů P. Vodohospodáři a správci povodí by měli pokračovat ve svém úsilí o maximální eliminaci zdrojů znečištění $P \vee$ povodí, protože vlivem dopadů změny klimatu pravděpodobně nebude možné dosáhnout požadovaného ekologického potenciálu podle RVS o vodě bez dalšího snížení zatížení fosforem, než k jakému do současnosti došlo.

\section{Poděkování}

Studie byla podpořena projektem Grantové agentury ČR č. 15-04034S: Odrážejí dlouhodobá data o zooplanktonu Slapské nádrže civilizační a/nebo klimatické změny $\checkmark$ minulých 50 letech? Autoři děkuji státnímu podniku Povodí VItavy za poskytnutí provoznich dat ze sledování jakosti vody a hydrologických ukazatelů, zejména pak pracovníkưm vodohospodářského dispečinku za spolupráci pri získávání provozních a hydrologických dat pro nádrže Vltavské kaskády z před-digitálního období.

Příspěvek byl publikován ve sborníku konference Vodní nádrže 2017, ISBN 978-80-905368-5-2.

\section{Literatura}

[1] BOROVEC, J. Vyhodnocení ekologického potenciálu silně modifikovaných a umëlých vodních útvarů kategorie jezero. Biologické centrum AV ČR, v. v. i., České Budějovice, 2013, $14 \mathrm{~s}$.

[2] BOWES, M.J., SMITH, J.T., JARVIE, H.P., NEAL, C., and BARDEN, R. Changes in point and diffuse source phosphorus inputs to the River Frome (Dorset, UK) from 1966 to 2006. Science of the Total Environment, 2009, roč. 407, p. 1954-1966.

[3] SMITH, V.H. and SCHINDLER, D.W. Eutrophication science: where do we go from here? Trends in Ecology and Evolution, 2009, 24, p. 201-207. 
[4] BAI, Z., MA, L., MA, W., OIN, W. VELTHOF, G.L., OENEMA, O., and ZHANG, F. Changes in phosphorus use and losses in the food chain of China during 1950-2010 and forecasts for 2030. Nutrient Cycling in Agroecosystems, 2016, 104, p. 361-372.

[5] JEPPESEN, E., KRONVANG, B., OLESEN, J.E., AUDET, J., et al. Climate change effects on nitrogen loading from cultivated catchments in Europe: Implications for nitrogen retention, ecological state of lakes and adaptation. Hydrobiologia, 2011, 663, p. 1-21.

[6] VAN VLIET, M.T.H., FRANSSEN, W.H.P., YEARSLEY, J.R., LUDWIG, F., HADDELAND, I., LETTENMAIER, D.P., and KABAT, P. Global river discharge and water temperature under climate change. Globd Environmental Change, 2013, 23, p. 450-464

[7] GEBRE, S., BOISSY, T., and ALFREDSEN, K. Sensitivity to climate change of the thermal structure and ice cover regime of three hydropower reservoirs. Journal of Hydrology, 2014, 510, p. 208-227.

[8] FLAIM, G., ECCEL, E., ZEILEIS, A., TOLLER, G., CERASINO, L., and OBERTEGGER, U. Effects of re-oligotrophication and climate change on lake thermal structure. Freshwater Biology, 2016, 61, p. 1802-1814

[9] WETZEL, R.G. Limnology: Lake and River Ecosystems, Third Edition. Academic Press, 2001

[10] HEJZLAR, J., ŠÁMALOVÁ, K., BOERS, P., and KRONVANG, B. Modelling phosphorus retention in lakes and reservoirs. Water, Air, and Soil Pollution: Focus, 2006, 6, p. 487-494.

[11] VOLLENWEIDER, R. A. Input-output models with special reference to the phosphorus loading concept in limnology. Schweizerische Zeitschrift Hydrobiologie, 1975, 37, p. 53-84.

[12] CHAPRA, S.C. Comment on 'An empirical method of estimating the retention of phosphorus in lakes', by W. B. Kirchner and P. J. Dillon. Water Resources Research, 1975, 2, p. 1033-1034.

[13] PRAIRIE, Y.T. Statistical models for the estimation of net phosphorus sedimentation in lakes. Aquatic Sciences, 1989, 51, p. 192-210.

[14] REYNOLDS, C.S. Eutrophication and the management of plankton algae: what Vollenweider couldn't tell us. In: Eutrophication: Research and Application to Water Supply (D.W. Sutcliffe, J.G. Jones, eds.). Freshwater Biological Association, Ambleside Cumbria, 1992, p. 4-29.

[15] BOROVEC, J., HEJZLAR, J. ZNACHOR, P. NEDOMA, J. ČTVRTLÍKOVÁ, M. BLABOLIL, P. Ř́lHA, M KUBEČKA, J., RICARD, D. a MATĚNA, J. Metodika pro hodnocení ekologického potenciálu silně ovlivněných a umělých vodnich útvarü - kategoriejezero. SFŽP ČR, MŽP ČR a Biologické centrum AV ČR v. v. i., České Budějovice, 2014, 38 s.

[16] HRBÁČEK, J., PROCHÁZKOVÁ, L., STRAŠKRABOVÁ-PROKEŠOVÁ, V., and JUNGE, C.O. The relationship between the chemical characteristics of the Vltava River and Slapy Reservoir with an Appendix Chemical Budget for Slapy Reservoir. In: Hydrobiological Studies 1 (J. Hrbáček, ed.). Academia, Prague 1966, p. 41-84

[17] POPOVSKÝ, J. Determination of total phosphorus in fresh waters. International Review of Hydrobiology, 1970, 55, p. 435-443.

[18] KOPÁČEK, J. and HEJZLAR, J. Semi-micro determination of total phosphorus in fresh waters with perchloric acid digestion. International Journal of Environmental Analytical Chemistry, 1993, 53, p. 173-183.

[19] HIRSCH, R.M., SLACK, J.R., and SMITH, R. Techniques of trend analysis for monthly water quality. Water Resources Research, 1982, 18, p. 107-121.

[20] MURDOCH, P.S. and SHANLEY, J.B. Detection of water quality trends at high, median, and low flow in a Catskill Mountain stream, New York, through a new statistical method. Water Resources Research, 2006, 42, No. W08407.

[21] SAS, H. (ed.) Lake Restoration by Reduction of Nutrient Loading: Expectations, Experiences, Extrapolations. Academia-Verl. Richarz, St. Augustin, 1989

[22] Nürnberg, G.K. Assessing internal phosphorus load - Problems to be solved. Lake and Reservoir Management, 2009, 25, p. 419-432.

[23] NORTH, R.L., JOHANSSON, J., VANDERGUCHT, D.M., DOIG, L.E., LIBER, K., LINDENSCHMIDT, K.-E. BAULCH, H. and HUDSON, J.J. Evidence for internal phosphorus loading in a large prairie reservoir (Lake Diefenbaker, Saskatchewan). Journal of Great Lakes Research, 2015, 41 (Suppl. 2), p. 91-99.

[24] SONG, K. and BURGIN, A.J. Perpetual Phosphorus Cycling: Eutrophication Amplifies Biologica Control on Internal Phosphorus Loading in Agricultural Reservoirs. Ecosystems, 2017, 20, p. 1483-1493.

[25] KUNZ, M.J., SENN, D.B., WEHRLI, B. MWELWA, E.M., and WUEST, A. Optimizing turbine withdrawa from a tropical reservoir for improved water quality in downstream wetlands. Water Resources Research, 2013, 49, p. 5570-5584.

[26] JAN, J., BOROVEC, J., PETRÁŠ, D., OSAFO, N., TOMKOVÁ, I. a HUBÁČEK, T. Vliv dostupnosti akceptorů elektronů na biogeochemické procesy a cyklus fosforu v sedimentu. In: Sborník konference Vodni nádrže 2017 (KOSOUR, D. et al., eds.), Povodí Moravy, s. p., Brno, 2017, p. 80-85.

[27] JOCHIMSEN, MC, KUMMERLIN, R, and STRAILE, D. Compensatory dynamics and the stability of phytoplankton biomass during four decades of eutrophication and oligotrophication. Ecology Letters, 2013, 16, p. 81-89.

[28] NORTH, R.P., LIVINGSTONE, D.M., HARI, R.E., KÖSTER, O., NIEDERHAUSER, P., and KIPFER, R. The physical impact of the late 1980 s climate regime shift on Swiss rivers and lakes. Inland Waters, 2013, 3 p. 341-350.

[29] TEMNERUD, J. and WEYHENMEYER, G.A. Abrupt changes in air temperature and precipitation: Do they matter for water chemistry? Global Biogeochemical Cycles, 2008, vol. 22, No. 2, GB2008.

[30] VYSTAVNA, Y., HEJZLAR, J., and KOPÁČEK, J. Long-term trends of phosphorus concentrations in an artificial lake: Socio-economic and climate drivers. PloS ONE 12 (10), e0186917.

\section{Autoři}

doc. Ing. Josef Hejzlar, CSc.

凶hejzlar@hbu.cas.cz

Ing. Jiří Jarošík

凶jiri.jarosik@hbu.cas.cz

prof. Ing. Jiří Kopáček, Ph.D.

凶jkopacek@hbu.cas.cz

Yuliya Vystavna, Ph.D.

凶yuliya.vystavna@hbu.cas.cz

Biologické centrum Akademie věd ČR, v. v. i., Hydrobiologický ústav

Příspěvek prošel lektorským řízením.

\section{TRENDS IN DEVELOPMENT OF PHOSPHORUS CONCENTRATIONS IN ORLÍK AND SLAPY RESERVOIRS}

\section{HEJZLAR, J.; JAROSIK, J.; KOPACEK, J.; VYSTAVNA, Y.}

Biology Centre of the Czech Academy of Sciences, p. r. i.

Keywords: eutrophication - phosphorus retention socio-economic indicators - climate change

Based on existing phosphorus data series in the Slapy and Orlík reservoirs and their main tributaries, we reconstructed $P$ inputs to the reservoirs from the catchment during 1961-2016 and compiled empirical models of $P$ retention. P concentrations in both reservoirs increased from the 1960's to 1991 and then declined, with the Slapy Reservoir having a significantly increased year-on-year variability. Trends in the increase and decrease of $\mathrm{P}$ reflected the socio-economic development in the Vltava river basin, in particular sewerage, wastewater discharges, fertilizer application, livestock, and fishpond fisheries. Analysis of $\mathrm{P}$ retention $\mathrm{P}$ in reservoirs showed that $\mathrm{P}$ accumulated in sediments during the 1961-1990 period of increasing P-load from the catchment was again partly released into water in the subsequent period of decreasing $P$ load and dampened the effect of decreasing $P$ concentrations in the reservoir tributaries. In the Slapy reservoir after 1991, the P concentrations increased during wet summers and created conditions for growth of phytoplankton, whereas in dry summers they decreased to mesotrophy. Climatic and hydrological processes have now apparently begun to compete with a generally decreasing $\mathrm{P}$ pollution and support eutrophication despite the drop in P loads from the catchment. 